\title{
PENINGKATAN PRESTASI BELAJAR BAHASA INDONESIA DENGAN MODEL PEMBELAJARAN AUDITORY INTELLECTUALLY REPETITION (AIR)
}

\author{
Widodo \\ SMP Negeri 2 Nguter, Kabupaten Sukoharjo \\ widowidodo24@yahoo.co.id
}

\begin{abstract}
Abstrak
Penelitian ini bertujuan untuk meningkatkan prestasi belajar bahasa Indonesia melalui model pembelajaran Auditory Intellectually Repetition (AIR) pada siswa kelas VIII C SMP Negeri 2 Nguter semester 1 tahun pelajaran 2017/ 2018. Penelitian ini adalah Penelitian Tindakan Kelas yang dilakukan di kelas VIII C SMP Negeri 2 Nguter semester 1 tahun pelajaran 2017/ 2018 yang berjumah 32 siswa. Teknik pengumpulan data yang digunakan adalah tes, observasi, dan dokumentasi. Tahap-tahap analisis data dalam penelitian ini adalah pengumpulan data, reduksi data, penyajian data, dan penarikan kesimpulan. Indikator keberhasilan adalah nilai rata-rata tes siswa sekurang-kurangnya 75,0 dan banyak siswa dengan nilai di atas kriteria ketuntasan minimal (KKM) yaitu 70,0 mencapai $\geq 85 \%$. Berdasarkan penelitian yang telah dilakukan, dapat disimpulkan bahwa penerapan model pembelajaran Auditory Intellectually Repetition (AIR) dapat meningkatkan prestasi belajar bahasa Indonesia pada siswa Kelas VIII C semester 1 SMP Negeri 2 Nguter tahun pelajaran 2017/ 2018. Hal ini dapat ditunjukan dengan meningkatnya nilai keterampilan menulis bahasa Indonesia siswa dari 69,1 meningkat menjadi 77,6 $\geq 75,0$ dan persentase ketuntasan belajar siswa dari $46,88 \%$ meningkat menjadi $87,5 \% \geq 85 \%$.
\end{abstract}

Kata Kunci: Model pembelajaran Auditory Intellectually Repetition(AIR), prestasi belajar bahasa Indonesia

\begin{abstract}
This study aims to improve the Indonesian language learning achievement through Auditory Intellectually Repetition (AIR) learning model in students of VIII C SMP Negeri 2 Nguter first semester academic year 2017/ 2018.This research is a Classroom Action Research conducted in class VIII C SMP Negeri 2 Nguterfirst semester of academic year 2017/2018 with 32 students. Data collection techniques used are tests, observations, and documentation. The stages of data analysis in this study are data collection, data reduction, data presentation, and conclusion. The success indicator is the average score of the student's test at least 80,0 and many students with a value above the minimum mastery criteria (KKM) of 70,0 reach $\geq 85 \%$. Based on the research that has been done, it can be concluded that the application of Auditory Intellectually Repetition (AIR) learning mdel can improve Indonesian language learning achievement in student of VIII C SMP Negeri 2 Nguter first semester academic year 2017/2018. This is indicated by the improvement of student's writing competence score from 69,1 into 77,6 $\geq 80,00$ and the percentage of student's minimum mastery criteria increases from $46,88 \%$ into $87,5 \% \geq 85 \%$.
\end{abstract}

Keywords: Auditory Intellectually Repetition (AIR) learning model, Indonesian language learning achievement. 


\section{PENDAHULUAN}

Mata pelajaran Bahasa Indonesia sangatlah penting untuk diberikan kepada siswa untuk semua jenjang pendidikan agar siswa dapat memiliki kemampuan berpikir kritis, rasional, dan kreatif dalam apresiasi dan komunikasi dalam kehidupan yang sebenarnya dalam masyarakat. Adapun tujuan Mata Pelajaran Bahasa Indonesia menurut Standar Isi antara lain agar peserta didik memiliki kemampuan: (1) Berkomunikasi secara efektif dan efisien sesuai dengan etika yang berlaku, baik secara lisan maupun tulis; (2) Menghargai dan bangga menggunakan bahasa Indonesia sebagai bahasa persatuan dan bahasa negara; (3) Memahami bahasa Indonesia dan menggunakannya dengan tepat dan kreatif untuk berbagai tujuan; (4) Menggunakan bahasa Indonesia untuk meningkatkan kemampuan intelektual, serta kematangan emosional dan sosial; (5) Menikmati dan memanfaatkan karya sastra untuk memperluas wawasan, memperhalus budi pekerti, serta meningkatkan pengetahuan dan kemampuan berbahasa; (6) Menghargai dan membanggakan sastra Indonesia sebagai khazanah budaya dan intelektual manusia Indonesia.Sedangkan ruang lingkup mata pelajaran Bahasa Indonesia antara lain (1) Mendengarkan; (2) Berbicara; (3) Membaca; (4) Menulis.

Sebagai institusi pendidikan formal, sekolah memiliki fungsi dan peran strategis dalam melahirkan generasi-generasi masa depan yang terampil berbahasa Indonesia secara baik dan benar. Melalui pembelajaran bahasa Indonesia, para peserta didik diajak untuk berlatih dan belajar berbahasa melalui aspek keterampilan mendengarkan, berbicara, membaca, dan menulis. Dengan memiliki keterampilan berbahasa Indonesia secara baik dan benar, kelak mereka diharapkan menjadi generasi yang cerdas, kritis, kreatif, dan berbudaya.

Salah satu aspek keterampilan berbahasa yang sangat penting peranannya dalam upaya melahirkan generasi masa depan yang cerdas, kritis, kreatif, dan berbudaya adalah keterampilan menulis. Namun, harus diakui secara jujur, keterampilan menulis di kalangan siswa SMP, belum seperti yang diharapkan. Kondisi ini tidak lepas dari proses pembelajaran bahasa Indonesia di sekolah yang dinilai telah gagal dalam membantu siswa terampil berpikir dan berbahasa 
sekaligus. Yang lebih memprihatinkan, ada pihak yang sangat ekstrim berani mengatakan bahwa tidak ada mata pelajaran Bahasa Indonesia pun siswa dapat berbahasa Indonesia seperti saat ini, asalkan mereka diajari berbicara, membaca, dan menulis oleh guru (Depdiknas 2004:9).

Sementara itu, hasil observasi empirik di lapangan juga menunjukkan fenomena yang hampir sama. Keterampilan mendengarkan siswa SMP berada pada tingkat yang rendah; diksi (pilihan kata)-nya payah, kalimatnya tidak efektif, strukturnya rancu, alurnya pun tidak runtut dan kohesif. Demikian juga keterampilan menulis siswa kelas VIII C SMP Negeri 2 Nguter. Berdasarkan hasil observasi, hanya $25 \%$ ( 8 siswa) dari 32 siswa yang dinilai sudah terampil menulis surat dinas. Indikator yang digunakan untuk mengukur keterampilan siswa dalam menulis, di antaranya mengidentifikasi bagian-bagian kepala surat, badan surat, dan kaki surat secara lengkap.

Dapat diketahui bahwa siswa kelas VIII C SMP Negeri 2 Nguter tahun pelajaran 2017/ 2018 yang sebanyak 32 siswa. Dari 32 siswa ini dapat di kategorikan keterampilan menulis bahasa Indonesia siswa masih rendah, hal ini dapat dilihat dari nilai rata-rata siswa yaitu 69,1 pada pretest keterampilan menulis dialog interaktif. Dari 32 siswa, sebanyak 17 siswa $(53,13 \%)$ masih di bawah nilai kriteria ketuntasan (KKM) yaitu 70,0.

Pengertian hasil telah dikemukakan beberapa ahli, sehingga dapat digunakan untuk batasan dari pengertian hasil. Menurut W.J.S Purwadarminta (dalam Hamdani, 2011:137), "Hasil adalah hasil yang telah dicapai (dilakukan, dikerjakan, dan sebagainya)'. Menurut Harahap (dalam Hamdani, 2011:138), Hasil adalah penilaian pendidikan tentang perkembangan dan kemajuan siswa yang berkenaan dengan penguasaan bahan pelajaran yang disajikan kepada mereka serta nilai-nilai yang terdapat kurikulum.

Pengertian belajar yang dikemukakan para ahli, sehingga dapat digunakan untuk membahas batasan dari belajar. Menurut Hamdani (2011:21), Belajar merupakan perubahan tingkah laku atau penampilan, dengan serangkaian kegiatan. Menurut Slameto (2003:2), Belajar ialah suatu proses usaha yang dilakukan seseorang untuk memperoleh suatu perubahan tingkah laku yang baru secara 
keseluruhan sebagai hasil pengalamannya sendiri dalam interaksi dengan lingkungannya.

Prestasi belajar bahasa Indonesia pada penelitian ini dibatasi pada keterampilan menulis. Menulis dapat didefinisikan sebagai suatu kegiatan penyampaian pesan (komunikasi) dengan menggunakan bahasa tulis sebagai alat medianya (Suparno, 2008: 1.3). Sementara Tarigan (2008: 22), menyatakan, menulis adalah menemukan atau melukiskan lambang-lambang grafik yang menggambarkan suatu bahasa yang dipahami oleh seseorang sehingga orang lain dapat membaca lambang-lambang grafik tersebut kalau mereka memahami bahasa dan gambaran grafik itu.

Pengertian model pembelajaran dikemukakan para ahli, sehingga dapat digunakan untuk membahas batasan dari pengertian model pembelajaran. Menurut Mills (dalam Suprijono, 2013:45), "Model pembelajaran merupakan bentuk representasi akurat sebagai proses aktual yang memungkinkan seseorang atau sekelompok orang mencoba bertindak berdasarkan model itu". Menurut Arends (dalam Suprijono, 2013:46), "Model pembelajaran mengacu pada pendekatan yang akan digunakan, termasuk di dalamnya tujuan-tujuan pembelajaran, tahap-tahap dalam kegiatan pembelajaran, lingkungan pembelajaran dan pengelolaan kelas”.

Model pembelajaran Auditory Intellectually Repetition (AIR) merupakan salah satu model pembelajaran yang menekankan tiga aspek yaitu Auditory (mendengar), Intellectually (berpikir), Repetition (pengulangan). Menurut Shoimin (2014:29), "Belajar Auditory, yaitu belajar mengutamakan berbicara dan mendengar".

Menurut Erman Suherman (dalam Shoimin, 2014:29), “Auditory bermakna belajar haruslah melalui mendengarkan, menyimak, berbicara, presentasi, argumentasi, mengemukakan pendapat dan menanggapi”. Menurut Dave Meier (dalam Shoimin, 2014:29), "Intellectually menunjukkan apa yang dilakukan pembelajaran dalam pemikiran suatu pengalaman dan menciptakan hubungan makna, rencana, dan nilai dari pengalaman tersebut". Menurut Erman Suherman (dalam Shoimin, 2014:29), "Repetition merupakan pengulangan, dengan tujuan 
memperdalam dan memperluas pemahaman siswa yang perlu dilatih melelui pengerjaan soal, pembagian tugas dan kuis.

Kegiatan belajar mengajar dapat berjalan dengan baik dan efektif diperlukan usaha yang sungguh-sungguh dari semua pihak. Peran guru sangat penting karena berfungsi sebagai komunikator yaitu menyampaikan pesan (materi) kepada siswa sebagai bekal siswa setelah menyelesaikan studinya dan dapat digunakan dalam kehidupan sehari-hari. Alternatif model pembelajaran yang dapat digunakan adalah dengan menggunakan model pembelajaran baru, salah satunya dengan model pembelajaran Auditory Intellectually Repetition (AIR). Model pembelajaran Auditory Intellectually Repetition (AIR) merupakan salah satu model pembelajaran yang menekankan tiga aspek yaitu Auditory (mendengar), Intellectually (berpikir), Repetition (pengulangan). Model pembelajaran ini memberi tekanan kepada siswa untuk mampu berinteraksi dengan lingkungannya.

Proses pembelajaran Auditory Intellectually Repetition (AIR) berlangsung secara bertahap yaitu, mulai siswa menerima stimulus dari guru, kemudian siswa dapat bekerjasama dengan kelompoknya, kemudian siswa mampu menggunakan kemampuan untuk menggunakan kemampuan berpikir, kemudian siswa memperoleh kuis atau pemberian tugas dari guru. Pemberian tugas, diharapkan siswa lebih terlatih dalam menggunakan pengetahuan yang didapat dalam menyelesaikan soal dan mengingat apa yang telah diterima, sementara pemberian kuis dimaksudkan siswa siap menghadapi ujian atau tes yang dilaksanakan sewaktu-waktu serta melatih daya ingat. Model pembelajaran ini mendukung siswa untuk mengembangkan diri dalam bekerja sama, mengeluarkan pendapat dan mampu menelaah materi lebih baik.

Berdasarkan uraian di atas, maka dapat dirumuskan tujuan penelitian sebagai berikut: "Meningkatkan prestasi belajar bahasa Indonesia melalui penerapan model pembelajaran AIR pada siswa kelas VIII C semester 1 SMP Negeri 2 Nguter tahun pelajaran 2017/ 2018". 


\section{METODE PENELITIAN}

Penelitian ini adalah Penelitian Tindakan Kelas. Penelitian tindakan kelas merupakan suatu pencermatan terhadap kegiatan yang sengaja dimunculkan, dan terjadi dalam sebuah kelas (Arikunto, 2010: 130).Penelitian ini dilaksanakan di SMP Negeri 2 Nguter. Tahap-tahap pelaksanaan kegiatan dilakukan selama kurang lebih lima bulan yaitu sejak bulan Juli sampai dengan November 2017. Peneliti sebagai guru SMP Negeri 2 Nguter bertindak sebagai subjek yang melakukan tindakan kelas. Teman sejawat sesama guru mata pelajaran bahasa Indonesia sebagai observer. Kepala Sekolah bertindak sebagai subjek yang membantu dalam perencanaan dan pengumpulan data. Subjek yang menerima tindakan adalah siswa kelas VIII C SMP Negeri 2 Nguter semester 1 tahun pelajaran 2017/ 2018 sebanyak 32 siswa.

Teknik pengumpulan data yang digunakan adalah: tes, observasi dan dokumentasi. Tes adalah serentetan pertanyaan atau latihan serta alat lain yang digunakan untuk mengukur keterampilan, pengetahuan inteligensi, kemampuan atau bakat yang dimiliki oleh individu dan kelompok (Arikunto, 2010 : 193). Tes digunakan adalah jenis tes hasil (achievement test) berupa kuis individu.Tes ini digunakan untuk mengukur pencapaian siswa setelah mempelajari materi. Hal ini dapat juga sebagai alat untuk mengetahui tingkat pemahaman siswa setelah mempelajari materi dengan menggunakan model pembelajaran AIR. .Kuis individu yang dimaksudkan ini adalah tes tertulis. Tes tertulis adalah suatu teknik penilaian yang menunutut jawaban secara tertulis, baik berupa pilihan atau isian. Tes yang jawabannya berupa pilihan meliputi pilihan ganda, benar salah dan menjodohkan, sedangkan tes yang jawabannya berupa isian berbentuk isian singkat atau uraian (Suprijono, 2013:138). Observasi atau pengamatan dilakukan guna memperoleh data yang akurat, dengan menggunakan lembar observasi.

Lembar observasi digunakan untuk memonitor dan mengevaluasi setiap tindakan agar kegiatan observasi tidak terlepas dari konteks permasalahan dan tujuan penelitian. Observasi yang digunakan adalah observasi sistematis, yaitu observasi yang dilakukan oleh pengamat dengan menggunakan pedoman sebagai instrumen pengamatan dan observasi non-sistematis yang dilakukan dengan tidak 
menggunakan instrumen pengamatan.Dokumentasi diperoleh dari hasil kuis siswa, lembar observasi, lembar wawancara, catatan lapangan, daftar siswa, dan foto-foto selama proses kegiatan belajar mengajar. Dokumentasi ini dimaksudkan adalah sebagai bukti-bukti konkret dari penelitian tindakan kelas tersebut.

Instrumen yang digunakan dalam penelitian berupa tes, lembar observasi dan lembar dokumentasi. Tes berbentuk tes tertulis maupun lisan yang dilakukan dalam post test dan kuis individu. Tes ini digunakan untuk mengetahui sejauh mana peningkatan prestasi belajar menulis surat dinas dengan penerapan model pembelajaran AIR. Lembar Observasi, digunakan lembar observasi prestasi belajar siswa dan lembar observasi pelaksanaan pembelajaran. Lembar observasi digunakan pada setiap pembelajaran sehingga kegiatan observasi tidak terlepas dari konteks permasalahan dan tujuan penelitian, untuk lembar prestasi belajar siswa digunakan pada saat siswa dapat menyelesaikan permasalahan dengan kegiatan belajar mengajar dan sedangkan lembar observasi pelaksanaan kegiatan belajar mengajar dengan model pembelajaran AIR digunakan sebagai pedoman peneliti dalam melakukan observasi pelaksanaan kegiatan belajar mengajar dengan menggunakan model pembelajaran AIR. Lembar dokumentasi ini bertujuan untuk mengetahui data siswa selama kegiatan penelitian berlangsung. Lembar dokumentasi ini berupa, foto-foto kegiatan pembelajaran, daftar hadir kegiatan pembelajaran, daftar hadir, daftar nilai, kartu pasangan soal/ jawaban dan sebagainya.

Indikator keberhasilan kinerja dalam penelitian ini adalah meningkatnya prestasi belajar bahasa Indonesia materi menulis surat dinas, yang ditunjukkan dengan meningkatnya nilai rata-rata tes siswa sekurang-kurangnya 75,0 dan banyak siswa dengan nilai di atas kriteria ketuntasan minimal (KKM) yaitu $\geq 70,0$ mencapai $\geq 85 \%$.

\section{HASIL DAN PEMBAHASAN}

Kondisi siswa pada pembelajaran prasiklus kurang mendukung. Pada pembelajaran prasiklus, guru menyampaikan pembelajaran secara klasikal. Proses pembelajaran berlangsung kurang lancar dan kurang komunikatif. Tanya jawab 
antara guru dengan siswa pun tidak komunikatif. Minat siswa untuk mengikuti pembelajaran masih kurang atau masih rendah.

Karena kondisi pembelajaran pada prasiklus masih kurang mendukung, hasilnya pun belum maksimal. Pada pembelajaran prasiklus nilai rata-rata prestasi belajar bahasa Indonesia siswa adalah 69,1 dengan penjelasan siswa yang tuntas atau mencapai KKM sebanyak 15 siswa atau 46,88\% dari jumlah siswa 32 orang. Nilai KKM yang harus dicapai siswa adalah 70,0. Dengan demikian, pada pembelajaran prasiklus masih terdapat 17 siswa yang belum tuntas atau 53,13\%. Siswa yang belum mencapai KKM ini harus dapat meningkat nilainya pada siklus I.

Hasil pembelajaran pada akhir siklus I ditemukan meningkat. Pada siklus I ini dari 32 siswa, yang dapat mencapai nilai KKM sebanyak 25 siswa. Persentase nilai siswa yang tuntas mengalami peningkatan sebesar $32 \%$. Pada awal kondisi terdapat 46,89\% siswa saja meningkat menjadi sebesar 78,13\%. Sedangkan siswa yang nilainya belum tuntas menurun jumlahnya menjadi 7 orang atau 21,87 \% siswa yang harus dituntaskan prestasi belajarnya.

Nilai perolehan prestasi belajar terendah sebesar 60 dan nilai tertinggi yaitu 90. Data tersebut menunjukkan bahwa hasil pembelajaran pada siklus I sudah mengalami peningkatan jika dibandingkan dengan pembelajaran pada fase prasiklus. Nilai rata-rata pada prasiklus adalah 69,1, sedangkan pada siklus I ratarata nilai siswa menjadi 76,4 . Peningkatan rata-rata nilai pada siklus I ini sangat berpengaruh terhadap ketuntasan nilai prestasi belajar bahasa Indonesia siswa. Pada pembelajaran prasiklus, persentase ketuntasan prestasi belajar siswa adalah $46,88 \%$. Pada pembelajaran prasiklus ini, guru belum mengambil suatu tindakan. Setelah guru melakukan refleksi dan tindakan pada siklus I, persentase ketuntasan prestasi belajar meningkat menjadi $78,13 \%$. Pada siklus I ini telah terjadi peningkatan persentase ketuntasan prestasi belajar.

Siklus II merupakan siklus terakhir dalam penelitian ini. Guru merencanakan pelaksanaan penelitian tindakan kelas (PTK) ini sebanyak 2 siklus. Kegiatan dimulai dari pembelajaran prasiklus, diteruskan pengambilan tindakan pada siklus I, dan finalnya, yaitu tindakan pada siklus II atau siklus terakhir. Setelah akhir 
pembelajaran siklus I, guru dan observer melakukan diskusi dan refleksi. Hasil analisis terhadap nilai siswa dan observasi pada siklus I dijadikan acuan untuk pengambilan tindakan pada siklus II.

Pada siklus II ini, guru masih tetap menggunakan skenario pembelajaran seperti pada siklus I, karena pada siklus I hasil pembelajaran sudah menunjukkan peningkatan yang signifikan. Peningkatan itu bukan hanya pada rata-rata nilai siswa tetapi juga pada persentase ketuntasan nilai siswa. Pada siklus II ini pembelajaran berjalan lebih lancar. Para siswa sudah terkondisi dengan model yang diterapkan. Hal itu dapat dilihat pada nilai siswa yang mengalami peningkatan pada siklus II.

Untuk mengetahui perbandingan hasil pembelajaran yang meliputi nilai siswa dan persentase ketuntasan prestasi belajar siswa, berikut ini guru akan menyajikan sebuah tabel.Tabel itu berisi perbandingan nilai siswa dan ketuntasan prestasi belajar siswa pada pembelajaran prasiklus, siklus I, dan siklus II.

Peningkatan tidak hanya pada rata-rata nilai siswa tetapi juga pada persentase ketuntasan belajar siswa. Rata-rata nilai prestasi belajar bahasa Indonesia siswa pada prasiklus adalah 69,1 sedangkan pada siklus I adalah 76,4. Peningkatan nilai rata-rata siswa dari prasiklus ke siklus I adalah 76,4 . Nilai rata-rata siswa pada siklus II adalah 77,6 Jadi, terjadi peningkatan nilai siswa dari siklus I ke siklus II. Ketuntasan belajar siswa pada prasiklus adalah $46,88 \%$, sedangkan pada siklus I adalah $78,13 \%$. Persentase ketuntasan belajar siswa pada siklus II adalah 87,5 \%. Jadi, ada peningkatan persentase prestasi belajar siswa dari siklus I ke siklus II.

Diskripsi hasil pembelajaran siswa kelas VIII C Semester 1 tahun pelajaran 2017/ 2018 SMP Negeri 2 Nguter dapat dilihat pada grafik berikut. 


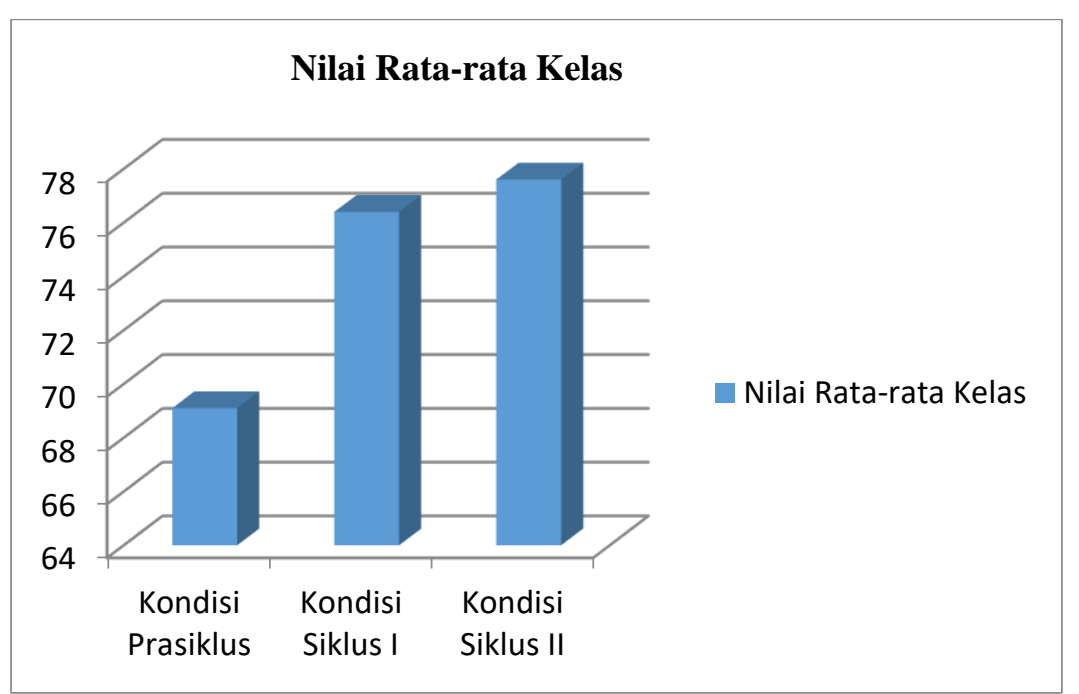

Gambar 1. Perkembangan Nilai Rata-rata Kelas Sebelum Tindakan/Prasiklus, Siklus I dan Siklus I

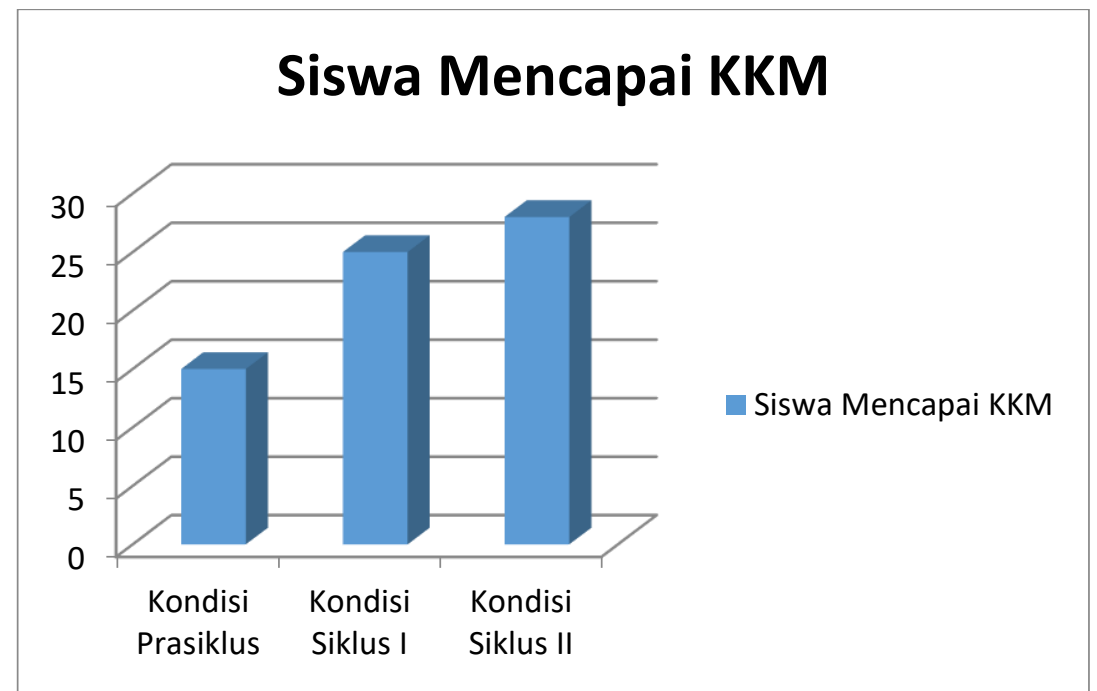

Gambar 2. Perkembangan Siswa yang Mencapai KKM Sebelum Tindakan/Prasiklus, Siklus I dan Siklus II

Tindakan siklus I dan II adalah suatu kegiatan yang dilakukan guru setelah menerapkan pembelajaran dengan model pembelajaran Auditory Intellectually Repetition (AIR). Kegiatan tindakan siklus I dilakukan untuk mengetahui kemampuan awal siswa dalam memahami materi. Kegiatan tindakan ini diikuti oleh seluruh siswa kelas VIII C yang berjumlah 32 siswa. Hasil dari kegiatan tindakan siklus I dan II ini berupa data tes. Data tersebut dijelaskan lebih rinci dalam hasil tes tindakan siklus I dan II pada Tabel 1. di bawah ini. 
Tabel 1. Nilai Prestasi belajar Bahasa Indonesia Siswa Selama Proses Pembelajaran Siklus I dan Siklus II

\begin{tabular}{llll}
\hline Aspek & Prasiklus & Siklus I & Siklus II \\
& & & \\
\hline Nilai Tertinggi & 85 & 90 & 90 \\
\hline Nilai Terendah & 60 & 60 & 65 \\
\hline Rata - rata & 69,1 & 76,4 & 77,6 \\
\hline $\begin{array}{l}\text { Ketuntasan } \\
\text { Klasikal }\end{array}$ & $46,88 \%$ & $78,13 \%$ & $87,5 \%$ \\
\hline
\end{tabular}

Nilai prestasi belajar bahasa Indonesia siswa meliputi rata-rata kelas, ketuntasan belajar individual dan ketuntasan belajar secara klasikal. Peningkatan pemahaman siswa sangat dipengaruhi keaktifan dan keterlibatan siswa dalam pembelajaran. Keaktifan dan keterlibatan siswa dalam proses pembelajaran merupakan salah satu faktor pendukung keberhasilan belajar. Hasil observasi terhadap proses pembelajaran siklus I tampak adanya peningkatan nilai rata-rata dibandingkan sebelum diterapkan pembelajaran dengan pendekatan pragmatik, juga diiringi dengan meningkatnya ketuntasan belajar siswa secara klasikal sebesar $31,3 \%$. Meningkatnya nilai prestasi belajar bahasa Indonesia siswa dari siklus I ke siklus II menunjukkan terjadinya peningkatan pemahaman terhadap materi yang dipelajari. Pemahaman pada siswa mulai menunjukkan peningkatan yang signifikan. Hal ini menunjukkan bahwa pembelajaran dengan model pembelajaran Auditory Intellectually Repetition (AIR) mampu meningkatkan nilai prestasi belajar bahasa Indonesia siswa. Akan tetapi, walaupun nilai prestasi belajar bahasa Indonesia siswa pada siklus I meningkat, namun peningkatan ini belum optimal karena belum sesuai dengan indika tor keberhasilan yang diharapkan, yaitu siswa yang memperoleh nilai $\geq 70,0$ kurang dari $85 \%$.

Pada siklus I, setelah mengalami tindakan dengan menggunakan pembelajaran dengan model pembelajaran Auditory Intellectually Repetition (AIR), terjadi peningkatan nilai prestasi belajar bahasa Indonesia siswa yang dilakukan oleh guru. Nilai terendah siswa adalah pada angka 60. Nilai tertinggi yang diraih siswa pada siklus I adalah 90. Nilai rata-rata akhir pada siklus I menjadi 76,4 , dan tercatat sebanyak 2 siswa telah melampaui nilai 70,0 sebagai batas KKM. 
Artinya peningkatan pemahaman materi menulis surat dinas pada proses pembelajaran dengan model pembelajaran Auditory Intellectually Repetition (AIR) ini mulai dirasakan manfaatnya bagi siswa. Namun masih ada $21,87 \%$ siswa yang belum tuntas KKM. Hal ini berarti belum memenuhi standar klasikal minimal ketuntasan klasikal. Untuk itu guru ,melakukan siklus yang ke II.

Pada awal siklus I ini, guru menemukan beberapa catatan lapangan yang menunjukkan peningkatan prestasi belajar siswa dari proses belajar dengan menggunakan pembelajaran dengan model pembelajaran Auditory Intellectually Repetition (AIR) dibanding sebelum adanya tindakan. Meskipun masih ditemukan beberapa siswa yang kurang aktif, namun paling tidak aktivitas belajar di dalam kelas terlihat lebih hidup dan peran serta siswa sebagai subyek penelitian semakin terasa. Hal ini mempengaruhi pemahaman dan penguasaan siswa akan kosa kata dalam Bahasa Indonesia semakin baik.

Pada siklus II, setelah mendapatkan penguatan dan bimbingan yang lebih intensif pada saat melaksanakan bermain peran dalam pembelajaran, didapatkan hasil yang sangat memuaskan yang didapatkan dari prestasi belajar siswa. Hasil tes yang diperoleh oleh kelas penelitian ini menunjukkan efek dan manfaat model pembelajaran Auditory Intellectually Repetition (AIR) bena-benar telah dirasakan manfaatnya oleh para siswa. Hal tersebut ditunjukkan seperti terlihat pada tabel di atas.

Pada siklus II ini, peningkatan nilai prestasi belajar bahasa Indonesia siswa ditunjukkan adanya peningkatan hasil tes akhir siklus II. Nilai terendah siswa masih ada yang mendapatkan nilai 65 dan nilai tertinggi siswa mencapai angka 90. Dan rata-rata kelas sudah melampaui angka ketuntasan minimal. Dari 32 siswa yang belajar dalam kelas, 28 anak telah mencapai kriteria ketuntasan minimal (KKM). Hal itu berarti ketercapaian ketuntasan klasikal mencapai 87,5\%. Dengan begitu kriteria ketuntasan klasikal telah tercapai.

Peningkatan keaktifan siswa dari siklus I menyebabkan nilai prestasi belajar bahasa Indonesia siswa pada siklus II juga cenderung meningkat. Peningkatan ratarata kelas dan jumlah siswa yang belajar tuntas ini menunjukkan bahwa pemahaman siswa terhadap materi pembelajaran meningkat. Pembelajaran dengan model 
pembelajaran Auditory Intellectually Repetition (AIR) mempunyai beberapa kelebihan. Kelebihan dari model pembelajaran Auditory Intellectually Repetition (AIR) adalah siswa dilibatkan untuk turut berpikir sehingga emosi siswa dapat terlibat langsung dalam proses pembelajaran, meningkatkan keterampilan siswa melalui suatu kegiatan, dapat mengamati suatu proses/kejadian dengan sendirinya, sehingga akan memperkaya pengalaman dan meningkatkan serta membangkitkan rasa ingin tahu. Siswa akan lebih memahami sesuatu yang bersifat abstrak dan lebih mampu mengingat dalam jangka waktu yang relatif lebih lama. Kelebihan model kegiatan dengan berlatih atau praktekcenderung menggali pengetahuan siswa dan menarik minat siswa dalam mengunakan kemampuannya berbicara dalam pelajaran Bahasa Indonesia. Hal ini menunjukkan bahwa siswa yang diajar dengan menggunakan pembelajaran dengan model model pembelajaran Auditory Intellectually Repetition (AIR) terdapat peningkatan prestasi belajar yang signifikan. Proses belajar mengajar selama siklus II masih terdapat kekurangan. Kendala yang dihadapi adalah dari dalam diri siswa, yaitu faktor psikis. Hal ini dapat diatasi dengan terampilnya guru dalam memotivasi dan menumbuhkan suasana belajar yang menyenangkan. Ketuntasan belajar klasikal pada siklus II sudah melebihi $85 \%$, hal ini berarti indikator kinerja untuk peningkatan persentase siswa yang memperoleh KKM 70,0 atau jumlah siswa yang belajar tuntas meningkat menjadi $\geq 85 \%$ sudah tercapai.

\section{SIMPULAN}

Berdasarkan penelilitian tindakan kelas ini, dapat diambil kesimpulan bahwa: penerapan model pembelajaran Auditory Intellectually Repetition (AIR) dapat meningkatkan prestasi belajar bahasa Indonesia pada siswa Kelas VIII C semester 1 SMP Negeri 2 Nguter tahun pelajaran 2017/ 2018. Hal ini dapat ditunjukan dengan meningkatnya nilai keterampilan menulis bahasa Indonesia siswa dari 69,1 meningkat menjadi $77,6 \geq 80,00$ dan persentase ketuntasan belajar siswa dari $46,88 \%$ meningkat menjadi $87,5 \% \geq 85 \%$. 


\section{REFERENSI}

Arikunto, Suharsimi. 2010. Prosedur Penelitian Suatu Pendekatan Praktik. Jakarta: Rineka Cipta.

Depdikbud. 2005. Kamus Besar Bahasa Indonesia. Jakarta : Balai Pustaka.

Hamdani. 2011. Strategi Belajar Mengajar. Bandung: Pustaka Setia.

Shoimin, Aris. 2014. 68 Model Pembelajaran Inovatif dalam Kurikulum 2013. Yogyakarta: Ae - Ruzz Media.

Slameto. 2003. Belajar dan Faktor - Faktor yang Mempengaruhinya. Jakarta: PT. Rineka Cipta.

Sugiyono. 2012. Metode Penelitian Pendidikan Pendekatan Kuantitatif, Kualitatif, dan $R \& D$. Bandung: Alfabeta.

Suprijono, Agus. 2013. Cooperative Learning .Yogyakarta: Pustaka Pelajar 